Indonesian Journal of EFL and Linguistics

Vol. 1 No. 1, 2016

eISSN: 2503-4197, pISSN: 2527-5070

www. indonesian-efl-journal.org

DOI: http://dx.doi.org/10.21462/ijefll.v1i1.3

\title{
Phonological System of Tengger Dialect in Ngoko Speech Level
}

\author{
Dwi Astuti Wahyu Nurhayati \\ IAIN Tulungagung, East Java, Indonesia \\ Email: dwiastuti_76@yahoo.co.id/dwiastuti705@gmail.com
}

\begin{abstract}
:
This research reports on Phonological System of Tengger Dialect (in Ngoko Speech Level) and focuses on how the consonant, vowel system, the syllabic, cluster construction are; what factors influence Phonological System Tengger Dialect in Ngoko Speech Level. Techniques of collecting data include field observations, recordings and direct interviews. The analysis includes reducing data, presenting the data, conclusion. Notes and phonetic transcription are classified into lingual unit, and they are written into version of ordinary words and form of symbols. Patterns of Tengger syllabic construction are: cvcvcv-kawula, cvc-nak, cvcvcparan, cccvcvvc-nggate'en, cvccv cekne, cv cvcvcvc -ta baliken, cvvcc-reang, different phonemic happens in suffix na $\rightarrow \sim$ en," Ta balikna ta baliken, nggatekna-nggate'en (from syllabic na en),jare $\rightarrow$ njare (embedded sound $\sim n$ before j). Different lexicon also happens in sesuk-kesuk-tomorrow, ora ana-nananothing.The factors contributing to the survival of the dialect are that the speakers live in remote and isolated area such as forest.
\end{abstract}

Keywords: phonological, system, Tengger, Dialect, Ngoko.

\section{INTRODUCTION}

Language is used to create a meaningful communication among human beings. In other words, communication is the main function of language. Communication is impossible without shared knowledge and assumptions between speakers and hearers (Stubbs in Nurhayati \&Yuwartatik, 2016a). Javanese is one of local languages in Indonesia. It has several dialects, one of which is Tengger dialect. It is used as a medium of communication in Tengger society covering Probolinggo, Pasuruan, Malang, Lumajang, East Java, Indonesia. Using a dialect is a part of 
speaking and it is defined as a process of using verbal and non-verbal symbols in any context (Nurhayati, 2016c). Tengger dialect has been being spoken by Tengger people since 1200s. It constantly survives because the users of the language would like to keep maintaining it as the anchestor's heritage.

Based on the previous studies, the history of development of Tengger dialect is not known clearly. Nancy's research (1985) does not touch upon the Tengger dialect. It merely discusses the development of Tengger society. They do not cope the unique parts and problematic either so it could not solve the system or the rule of Javanese Language Tengger Dialect as a result the uniqueness as the features of a language the system of Tengger Dialect does not appear (Kentjono ED, 1982; Chail, 1994). The research about Tengger tribe especially culture and language must still be observed deeply, a research of Tengger culture talks about Life Philosophy of Tengger Society and a book about Kasada Legend and Karo Orang Tengger Lumajang (Soetarto,1997).

In this study, phonemes of Tengger Dialect especially syllabic construction of phonological system of Tengger Dialect still rare to be observed, it stimulates the researcher to conduct a linguistic study to complete the thing that has been observed and take a title "Phonological System of Tengger Dialect ( in Ngoko Speech Level)". The research questions in this research are as follows: 1) How is the consonant system and vowel system of Tengger Dialect in Ngoko Speech Level?; 2) How is the construction syllabic of Tengger Dialect in Ngoko Speech Level?; 3) How is the construction cluster of Tengger Dialect in Ngoko Speech Level?; 4) What factors influence the forming of Phonological System of Tengger Dialect in Ngoko Speech Level?

This research is both theoretically and practically significant. The theoretical significance of this research is that it can provide description and explanation about the Phonological System of Tengger Dialect in Ngoko Speech Level. It also completes the description about the forming (formation) of word West Austronesia. It is caused by that language is a system of the elements and features (Samsuri, 1987) so as a dialect, Tengger Dialect has system of elements and features which are necessary to describe clearly. Developing phonological theory which will be got is the explanation about factors play role in identifying vowel system, consonant, syllable construction, cluster Tengger Dialect. It contributes the theory of phonemic.

The practical significance in this study is that it can establish and develop Tengger Dialect as the basis to develop text books of Tengger dialect. Related to preserving local culture at schools, the result of this study will be beneficial as the basic of arranging material of local content which support the students understand and preserve their own dialect, especially the ability to know and differentiate general Javanese dialect and Tengger dialect in Ngoko level, so the level of difficulties related to the difference system of language can be overcome.

This research can be done operationally because it gives contribution toward the use of Phonological System of Tengger Dialect especially in consonant and vowel system, syllable and cluster constructions, the construction distribution of sound 
(vowel, consonant, syllabic, and cluster) of Javanese Language Tengger Dialect in Ngoko Speech Level, and also to find out the what factors that influence phonological system of Tengger Dialect.

\section{REVIEWING RELATED LITERATURE}

Phonology as according to Dobrovolsky \& Katamba (1996) is the component of a grammar made up of the elements and principles that determine how pattern in a language sounds. It attempts to discover general principles that underlie the patterning of sounds in human language. The existence of pattern in language depends on the organization of certain basic elements or units that combine to make up these patterns.

Yule (1998: 57) defines that a syllable must contain a vowel (or vowel-like) sound. The most common type of syllable in language also has a consonant before the vowel, often represented as CV. Technically; the basic elements of the syllable are the onset (one or more consonants) and the rime. The rime (also written as 'rhyme') consists of the vowel, which is treated as the nucleus, plus any following consonant(s), treated as the coda.

Thus, syllables like me, to, or no has an onset and a nucleus, but no coda. They are known as 'open' syllables. When a coda is present, as in the syllables, up, cup, at or hat, they are called 'closed' syllables. The basic structure of the kind of syllable found in English words like green (CCVC), eggs (VCC), and (VCC), ham (CVC), I $(\mathrm{V})$, do $(\mathrm{CV})$, not $(\mathrm{CVC})$, like (CVC), them (CVC), Sam (CVC), I (V), am (VC), is shown in the accompanying figure 1.

Figure 1. The Division of Syllable

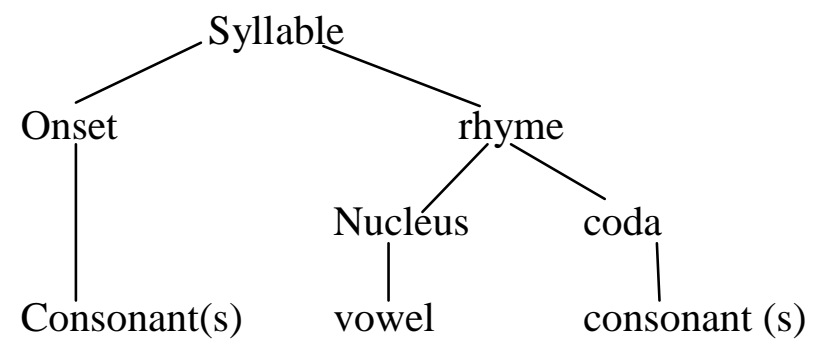

Both the onset and the coda can consist of more than one consonant; also know as a consonant cluster. The combination st is a consonant cluster (CC) as onset in the word stop, and as coda in the word post. There are many CC onset combinations permitted in English phonotactics, as in black, bread, trick, twin, and throw, with approximants $(/ \mathrm{w} /, / \mathrm{r} / . / \mathrm{l} /)$ frequently appears in the second position. (Note that throw begins with only two consonants $/ \varnothing \mathrm{r}$, once again showing that spelling is not a good guide in phonology. These consonant clusters are used as a way to analyse the consonant cluster of Tengger dialect.

It is further stated that four major unit analyses in this study reveal consonant and vowel system, syllabic, cluster construction. The properties of the syllable mean the 
basic unit in which segments are grouped. A syllable is a unit of linguistic structure that consists of a syllabic unit; normally a vowel and any segments that are associated with it. The third unit of phonological system is the feature. Features may be thought of as the smallest building blocks of phonological structure, corresponding as they do to articulator or acoustic categories but this study only focuses on four units above; vowel and consonant system, cluster, syllabic construction. The language users has to know what a word sound like (its pronunciation) and what it looks like (its spelling). These are fairly obvious characteristics and the other will be presented by the item for language user when encountering the item for the first time (Ur in Nurhayati, 2008a \& 2015b).

Dialect means local varieties used for various types informal situation or it is often thought of as standing outside the language or nonstandard language (Haugen in Wardhaugh, 2006). Tengger dialect is a dialect spoken in Bromo area of Mount Bromo included in Pasuruan, Probolinggo, Malang and Lumajang. In Pasuruan, Tengger dialect is found in Tosari Sub district, the in Probolinggo, area of Sukapura Sub district, whereas in Malang, Tengger dialect is spoken in Ngadas village, Pocokusumo Subdistrict. The last in Lumajang is spoken in Ranupane area, Senduro Sub district. This dialect is supposed as Javanese Kawi, it still has been preserving the ancient sentences which are no longer used in Modern Javanese. They use two level of language those are Ngoko, daily language to the peer, and Krama to the older or more respected people. In Tengger society there is no different caste, it means that they have the same position or social class.

There are some words of Tengger Dialect for example: Aku (laki-laki or a man) = Reang, Aku (woman)=isun. Kamu (for the same age)=Sira, Kamu (for the older people $)=$ Rika, Bapak $/$ Ayah $=$ pak, Ibu+ Mak, Kakek=Wek, kakak= Kang, Mbak=Yuk 'sis", Paran= apa "what, njare= gimana "how", Ngandi= kemana where are you going, nana= tidak ada "nothing”, ngapa= kenapa "why", (ngapa'a lare $)=$ kenapa rek? what's wrong?, kela paran= masak sayur apa/" what vegetables do you cook", ajo = jangan 'dont", ajo ngono= jangan begitu "don't do that. The letter of " $\mathrm{a}$ " in Modern Javanese is pronounced $\mathrm{O}$, in Tengger is pronounced A.

\section{RESEARCH METHOD}

Method of research is the steps or phases which are done by the researcher in order to the purpose of research. The research was done in Tengger Probolinggo Regency. Time of research is 4 (four) months from March until June 2013.

The data in this research are provided by using the list of questions designed by Bern Northofer which is modified. Besides that, it is used a model of telling or announcing something to someone else.

Providing data can be done by listening and speaking (Sudaryanto, 1993). In this case it is used recorded to check and if it happens unreliability or unclearness toward the data. The main respondents consist of two people, and then the compared respondents also consist of two people. The compared respondents are used to check the doubt things. Data in this research are primary and secondary data. The recording technique and questions- answer are used in primary data. 
The sources of data in this research are got from observation result and the result of direct interview also still used elicitations outside those data (Fernandez, 1993: 3), Samarin, 1988: 162). The list of questions is used to catch the lingual speech consisting of base, dialogue, simple sentences (DEPDIKBUD, 1996). List of questions is used to catch a lingual unit of informant which functions as instrument dialect research, especially to identify the aspect of phonology mainly vowel, consonant, syllable, cluster and phonological aspects which influence Dialect in every area as determined place of research.

Instrument of research is used in this study are observation technique and deep interview. The method of ethnography has unique features which differentiate from other qualitative method is: the observatory participant as technique of collecting data, the span of time of research longer relatively, in certain setting, deep interview and unstructured also the interpretation of the researcher, besides that it is also used field note and recording.

Phoneme, and the pattern of vowel "o" becomes "a" Javanese as modern of system of phonemic like what almost the same as Javanese dialect whether they are classified the same or not. Then the aspirated and unaspirated vowel if the finding of the same pattern of data are found are the same pattern and the theory can be elaborated with the phonemic change.

In implementing the research, it is done direct interview and participatory observation then followed by taking note or recording toward the unit lingual which is spoken by the informant then the data in the form of recording and taking note, the next transcribed in order to be observed, analyzed, and tested validity data through the triangulation test to examine or to test the reliability fact and evidence of Tengger Dialect.

Analysis data is a process to find out and manage the entire interview transcript, field note, and other collected materials systematically to get the information and experience about data and communicate what it is found (Bogdan \& Biklen 1992: 79). The activity of analysis data includes: manage, arrange, classify, give code, and categorize in order to determine the theme (Moleong, 2009: 281).

Data analysis case is an analysis adapt about the phonological system of Tengger Dialect become as study case. The analysis is done by; a) reducing data, b) presenting the data, c) conclusion (temporary conclusion, verification, and final conclusion). Those three phase analysis data are an integrated unit, the process interrelated and done many times during and after collecting data (Miles \& Huberman: 1987: 49).

In the preliminary phase the researcher utilizes the data of recorded/notes and phonetic transcription of Javanese Language Tengger Dialect based on the result of field research. The data of every place of research are classified in order to see every element of unit lingual of informant, not only in phonological system such as vowel, consonant, syllable, and cluster but also other variables in phonological system of Tengger Dialect. Then the difference data are described in tables based on the 
necessities. Presenting the result of data analysis is written in two versions, 1) version of ordinary words, 2) in the form of symbols.

\section{FINDINGS AND DISCUSSION}

Based on the research questions in this study, the data of Tengger dialect can be seen in the table below.

Table 1. Tengger Dialect, Javanese, Bahasa Indonesia and English

\begin{tabular}{|c|c|c|c|c|}
\hline Tengger Dialect & Javanese & Bahasa Indonesia & English & Explanation \\
\hline 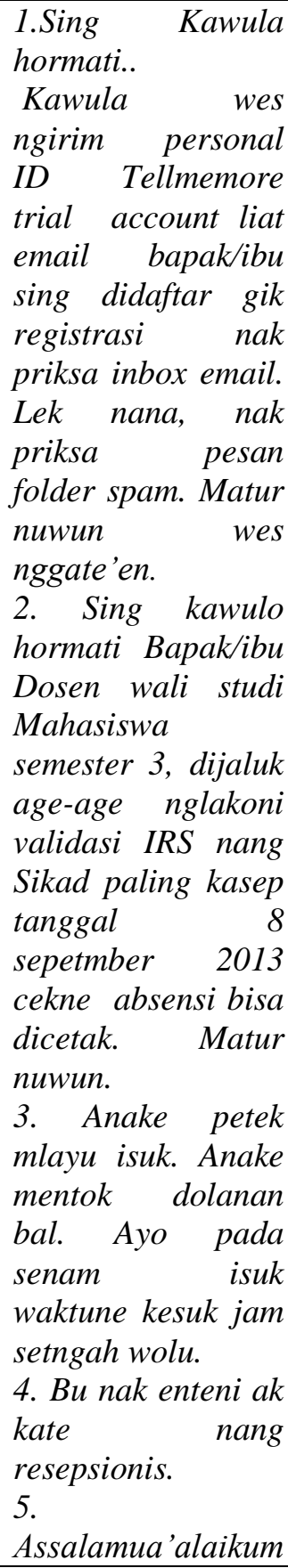 & \begin{tabular}{|l} 
Sing Kulo \\
Hormati \\
Kulo wis \\
ngirim \\
personal ID \\
Tellme more \\
trial account \\
deleng email \\
bapak/ibu \\
ndik \\
registrasi, \\
dipriksa \\
inbox email. \\
Yen gak \\
ono, ndang \\
diprikso \\
pesen folder \\
spam. Matur \\
nuwun wis \\
nggatekna.
\end{tabular} & 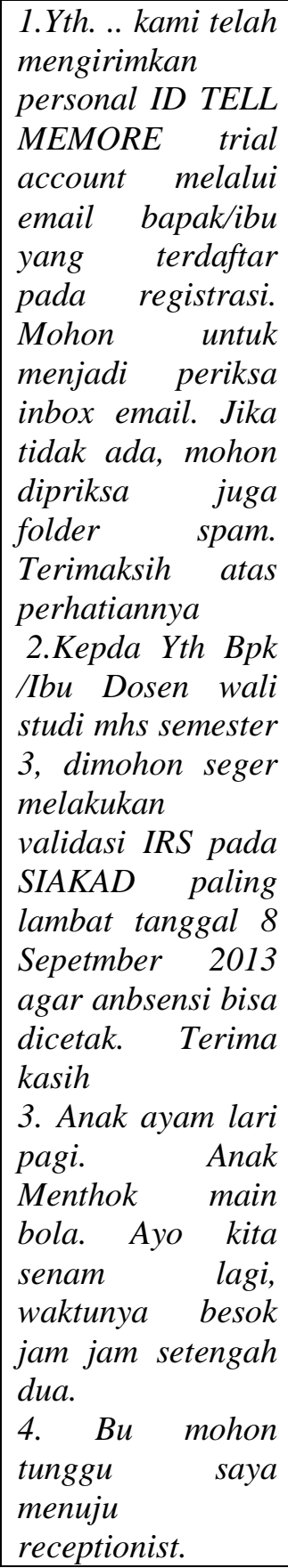 & 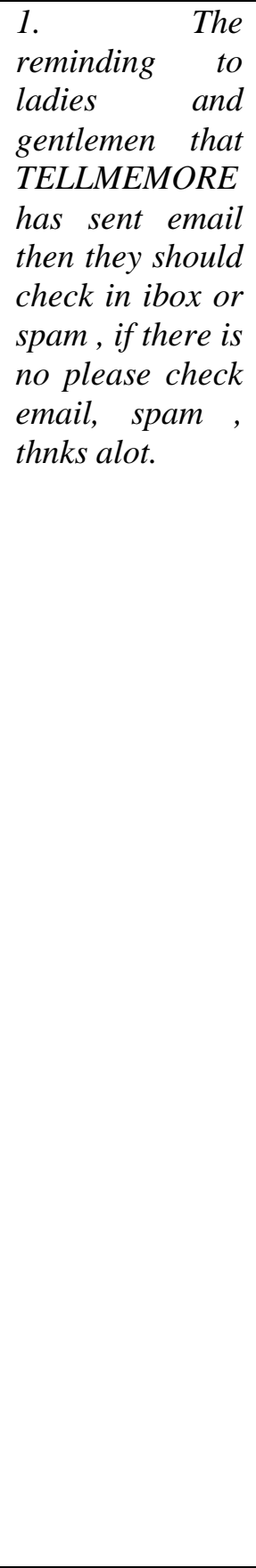 & $\begin{array}{l}\text { From the } \\
\text { Tengger } \\
\text { dialect it has } \\
\text { any changing } \\
\text { among these } \\
\text { dialects, } \\
\text { eventhough } \\
\text { there are } \\
\text { some different } \\
\text { lexicon the } \\
\text { words nak, } \\
\text { nana: } \\
\text { nothing, age- } \\
\text { age; cepat } \\
\text { hurry up,but } \\
\text { all the } \\
\text { utterances } \\
\text { still could be } \\
\text { understood. }\end{array}$ \\
\hline
\end{tabular}

Indonesian Journal of EFL and Linguistics, Vol. 1 (1), 2016 


\begin{tabular}{|c|c|}
\hline 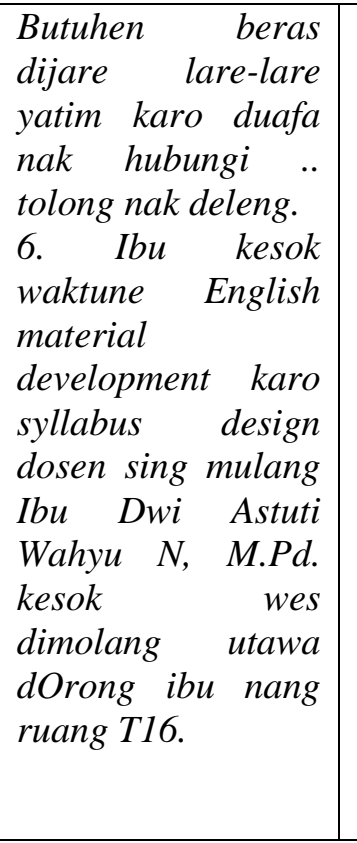 & \begin{tabular}{|lr} 
5Assalamualaikum \\
dibutuhkan beras \\
untuk anak-anak \\
yatim dan duafa \\
hubungi PA & Baitul \\
Yatim Jl. Raya \\
Saritamara 17 \\
Tandes Surabaya \\
Mohon dijenguk \\
6r Ibu besok \\
waktunya English \\
Curriculum dan \\
syllabus design \\
dosen pengajar \\
Dwi Astuti Wahu \\
N,M.Pd. Besok \\
sudah bisa dimulai \\
atau belum ibu \\
diruang T16.
\end{tabular} \\
\hline
\end{tabular}

Regarding the area of phonological system (see table1), as revealed from the informant's transcription, it seems that the vowel and consonant system of Tengger dialect has no much different construction from Javanese dialect. These indicate that there was no much different construction between Javanese and Tengger dialect. As revealed by Soedjito et.al. (1984) that the Structure of Javanese Tengger Dialect is not much different construction from Javanese dialect.

The informants 'transcription (see table 2) also show that the use of the consonants and vowels for different lexicon.

Table 2. The Consonant and Vowel System of Tengger Dialect

\begin{tabular}{|c|c|c|c|}
\hline No & Vowel & Consonant & Explanation \\
\hline 1 & $A, i, u e, o, E$ & $\begin{array}{l}b, c, d, f, g, h, j, k, l, m, n \\
, p, q, r, s, t, v, x, y, z\end{array}$ & $\begin{array}{l}\text { The Consonant system } \\
\text { of Tengger dialect has } \\
\text { the same consonants in } \\
\text { Javanese dialect in } \\
\text { general such as } b, c, d \text {, } \\
f, g, h, j, k, l, m, h, p, q, r, s \text {, } \\
t, v, x, y, z\end{array}$ \\
\hline
\end{tabular}

Based on the the data above it can be said that both of those dialects; Tengger dialect and Javanese dialect almost have the same system.

Table 3. The Construction Syllabic of Tengger Dialect

\begin{tabular}{|l|l|l|}
\hline Tengger Dialect & Syllabic Construction & Explanation \\
\hline 1.Sing Kawula hormati.. & CVCC CVCV CVCCVCV & The syllabic construction of \\
Kawula wes ngirim & Kawula: $C V C V C V$ & Tengger dialect almost have \\
\hline
\end{tabular}

Indonesian Journal of EFL and Linguistics, Vol. 1 (1), 2016 
personal ID Tellmemore trial account liat email bapak/ibu sing didaftar gik registrasi nak priksa inbox email. Lek nana, nak priksa pesan folder spam. Matur nuwun wes nggate'en.

2. Sing kawulo hormati Bapak/ibu Dosen wali studi Mahasiswa semester 3, dijaluk age-age nglakoni validasi IRS nang Sikad paling kasep tanggal 8 sepetmber 2013 cekne absensi bisa dicetak. Matur nuwun.

3. Anake petek mlayu isuk. Anake mentok dolanan bal. Ayo pada senam isuk waktune kesuk jam setngah wolu.

4. Bu nak enteni ak kate nang resepsionis.

5. Assalamua'alaikum

Butuhen beras dijare larelare yatim karo duafa nak hubungi .. tolong nak deleng. 6. Ibu kesok waktune English material development karo syllabus design dosen sing mulang Ibu Dwi Astuti Wahyu N, M.Pd. kesok wes dimolang utawa dOrong ibu nang ruang $T 16$.

Ta balikna ta baliken (from syllabic na en),jare $\rightarrow$ njare (embedded sound $n$ before j), e.g.1. 'Njare kabar rika? Reang njaluk tulung nyelang picis 300 ewu ana?'2.Isun njaluk tulung ayo gentenan picis
Wes: $C V C$

Lek Nana: $C V C C V C V$

Nggate'en: CCCVCVCV

Cekne: $\mathrm{CVCCV}$

Kesuk: $C V C V C$

Kate: $C V C V$

Nak; $C V C$

Age-age: $V C V V C V$

Njare: $C C V C V$

Baliken: $C V C V C V C$ the same but ther are some differencers happen in certain lexicon such as lek nana, ora ono means nothing, then kesuk + sesuk means tomorrow, kate = arep means will, then Nak= di means the passive form), age-age $=$ hurry up Njare: jare; said Baliken: balikna: give it back

Based on the data above it can be said that the syllabic construction of Tengger dialect has some variation but most of them happened in different lexicon. 
Table 4. The Cluster Construction of Tengger Dialect

\begin{tabular}{|c|c|c|}
\hline Tengger Dialect & Cluster Construction & Explanation \\
\hline $\begin{array}{l}\text { 1.Sing Kawula hormati.. } \\
\text { Kawula wes ngirim } \\
\text { personal ID Tellmemore } \\
\text { trial account liat email } \\
\text { bapak/ibu sing didaftar } \\
\text { gik registrasi nak priksa } \\
\text { inbox email. Lek nana, } \\
\text { nak priksa pesan folder } \\
\text { spam. Matur nuwun wes } \\
\text { nggate'en. }\end{array}$ & $\begin{array}{l}\text { There are some consonant } \\
\text { clusters in Tengger } \\
\text { dialect such as the word } \\
\text { nggate'en: }(C C C=\text { ngga) }\end{array}$ & $\begin{array}{l}\text { Not all the tengger word } \\
\text { has longer onset clusters, } \\
\text { indeed the syllabic } \\
\text { structure of this dailect is } \\
\text { predominantly } C V\end{array}$ \\
\hline
\end{tabular}

Based on the table above it can be said that most of the cluster construction are perdominatly by $\mathrm{CV}$ construction, and there is one longer onset consonat cluster happened in Nggate'en (CCCVCVVC)which has the same meaning in Nggatekne (CCCVCVCCV).

Then form the data taken from the interview, transcription and documentation fall within phonemic and some different lexicon. The patterns of Tengger syllabic construction are: cvcvcv-kawula, cvc-nak, cvcvc-paran, cccvcvvc-nggate'en, cvecv cekne, cv cvcvcvc -ta baliken, cvvcc-reang, then the different phonemic happens in suffix $\sim$ na $\rightarrow \sim$ en," Ta balikna ta baliken (from syllabic na en),jare $\rightarrow$ njare (embedded sound $n$ before j), e.g.l. 'Njare kabar rika? Reang njaluk tulung nyelang picis 300 ewu ana?'2.Isun njaluk tulung ayo gentenan picis. Different lexicon include paran what, picis money,manja plant, ngapa why ,gombal clothes.

Then the fourth of research question answered the factors influence the phonological system of Tengger that including from the history, cultural point of view instead of linguistic pointof view that something worth noting is that Tengger dialect is one part of Javanese Kawi, a language descended by Javanese ancentors in Majapahit Kingdom era. As the Kingdom inclined because of civil war, when Islam spreads out in Java, then Middle Javanese which was brought by Tengger people still maintained the phonological system of "a" become "o". Relic society as ancestor's heritage preserved informally then it is isolated, the tradition of way of life and cultural system are interesting to be observed. The Javanese people who live in Majapahit time are classified into Middle Javanese because of political crushed, then the society of Middle Javanese as the outsiders because they live isolated. Eventhough, the Middle Javanese contacted with the worldwide but they do not get changing with the language outside. The domination of ' $a$ ' sound seems strongly. This is parallel with a study of Kisyani-Laksono (1998) that isolect speakers know that there are any differences between Krama Inggil and Krama Andhap. It proves from their opinions states that the word which are used in Krama Inggil more polite than in Krama Andhap (they use both of them). The vocabulary of Krama Inggil 
generally is spoken to conduct activities, besides that it is also used to state noun for example [putO kulO]'anak saya', in standard dialect [ana/kulO] or [yogO kulO]. Principally there is difference use of isolect between Keduwung Atas and Keduwung Bawah. This difference seems relative difficult the connection of those area even though they are in the same village. From the language point of view, the difference shows that there are more relics of Keduwung Atas than in Keduwung Bawah. Totally, in Keduwung village, it is seen many forms of relics besides that there are innovative forms (such as konIN) dan pinjaman or borrowing (example: bentuk krama) but, commonly it can be seen that there are more forms of relics in Keduwung shows relics that innovative forms. Therefore it is more possible to say that isolect in Keduwung, especially in Keduwung Atas as Isolect Javanese language which presents relics element so the area of Kedawung Atas can be called as relic area of Javanese Language, as stated by cf. Smith-Hefner (1988) that the society of Keduwung Atas realizes their Javanese language is different from others. Therefore, they call their Javanese language as "Cara Tengger" then it was also stated by Sariono (1993) that Javanese dialect which is used in Keduwung Bawah and the lower area is called "cara isor". This means that conducting research related the dialect can be done not only the phonological system but also morphological and morphophonemic process of Alay variation and reveals that morphological processes including affixation e.g. internal change, infixation, and core vowel change; non affixation e.g. borrowing, coinage, clipping, acronym, multiple process, reduplication and combination text and morphophonemic process e.g. loss of phoneme, addition of phoneme, simple consonant change (Nurhayati, 2015a) and processes of word formation and technique understanding slang words used by Waria Tulungagung are divided into eleven processes i.e. Derivation, Multiple Process, Acronym, Borrowing, Blending, Reduplication, Synonym, Coinage, Irregular Form, Echoism, Changing of Syllable Vowel and the technique of understanding Waria sentences by removing some suffixes (Nurhayati, 2016b).

Because of living in remote area and having the same Javanese dialect are factors which influence on their phonological system. In other words it can be said that the factors contributing to the survival of the dialect are that the speakers live in remote and isolated area such as forest, as revealed by Prakoso (1997) and Sutoko et.al. (1985) that Suku Tengger has its own way or motivation it is as the choice of a particular action and the efforts expended on it and the persistence with it (Nurhayati, 2014b). The society life still holds the forefather's customs until now. It is tied up them tightly which is seldom to see.

\section{CONCLUSION}

This research provides some insight into the true condition of phological system of Tengger dialect as one of Javanese dialect which has almost the same system of vowel and consonant but have different slightly in syllabic and cluster construction. It also happened in different lexicon. The survival of this dialect could happen because of their highest loyalty to preserve heritage dialect from their ancestors and live in isolated area. Further research should be conducted by using other approach 
or point of view then it can be used as a step ahead of preserving local culture including dialect.

\section{REFERENCE}

Bogdan, R.C, \& Biklen, S.K,. (1992). Qualitative Research for Education: An Introduction to Theory and Methods. Boston: Allyn and Bacon, Inc.

Dobrovolsky, M., O Grady, W. \& Katamba, F. (1996). Contemporary Linguistics : An Introduction.United Kingdom: Pearson Education Limited.

Hock, Hans Henrich. (1986). Principles of Historical Linguistics. Berlin; New York; Amsterdam: Mouton de Gruyter.

Jacobson, R. (1982). Fundamental of Language. The Hague: Mouton.

Jensen, Klaus Bruhn and Nicholas W. Jankowski. (1991). A Handbook of Methodologies for Mass Communication Research.

Kisyani, L. (1995). "Bahasa Jawa Dialek Jawa Timur di Mojokerto: Kajian Geografi". Thesis. Yogyakarta:UGM.

Miles, H.B, \& Huberman, A.M,. (1987). Qualitative Data Analysis. London: Sage Publication.

Moleong, L.J,. (2009). Metodologi Penelitian Kualitatif. B Bandung: PT Remaja Rosdakarya.

Nasution, S,. (2003). Metode Penelitian Naturalistik:Kualitatif. Bandung: Tarsito.

Nurhayati, Dwi Astuti Wahyu. (2008a). Improving Students'English Vocabulary Mastery through Games (A Classroom Action Research in the Islam Kindergarten of Al-Irsyad Madiun in the Academic Year 2007/2008). Surakarta.Graduate School of Sebelas Maret University.

Nurhayati, Dwi Astuti Wahyu. (2014b). Using Picture Series to Inspire Reading Comprehension for the Second Semester Students of English Department of IAIN Tulungagung. Dinamika Ilmu Journal.Vol.14.No.2.Desember 2014: 176-189.

Nurhayati, Dwi Astuti Wahyu. (2015a). Morphological Process and Morphophonemic Process of Allay Variation.Lingua.Vol.12.No.1, March 2015.61-72.

Nurhayati, Dwi Astuti Wahyu. (2015b). Improving Students' English Pronunciation Ability through Go Fish Game and Maze Game. Dinamika Ilmu Journal.Vol 15 No 2, December 2015: 215-234.

Nurhayati, Dwi Astuti Wahyu \& Yuwartatik. (2016a). Illocutionary and Perlocutionary Acts on Main Characters Dialogues in John Milne's Novel: "The Black Cat". IJOLT, 1(1), January 2016.67-96. 
Nurhayati, Dwi Astuti Wahyu. (2016b). Word Formation Procesess and a Technique in Understanding Waria Slang Tulungagung. EFL Journal.Vol.1.No.1.March 2016.59-87.

Nurhayati, Dwi Astuti Wahyu. (2016c). Using Local Drama in Writing and Speaking: EFL Learners' Creative Expression. JELTL. Vol.1.No.1. April 2016. 51-77.

Mulyana, Deddy. (2001). Metodologi Penelitian Kualitatif: Paradigma Baru Ilmu Komunikasi dan Ilmu Sosial Lainnya. Bandung: PT Remaja Rosdakarya.

Sariono, Agus. (1993). Pergeseran Dialek Bahasa Jawa di Tengger. Jember.

Soedjito,dkk. (1994). Struktur Bahasa Jawa Dialek Tengger. Jakarta: Pusat Pembinaan dan Pengembangan Bahasa.

Sutoko, dkk. (1985). Geografi Bahasa Jawa Dialek Tengger. Jakarta: Pusat Pembinaan dan Pengembangan Bahasa.

Smith-Hefner, Nanci,J. (1988). Cara Tengger: Notes on a Non-Standard Dialect of Javanese. in Richard McGinn (Ed.). Studies in Austronesian Linguistics. Ohio University Center for International Studies for Southeast Asia Studies.

Wardhaugh, R. (2006). Introduction to Sociolinguistics. United Sates of America: Blackwell Publishing.

Yule, George. (1998). The Study of Language. London. Cambridge University Press. 